\title{
Just Above the Fray - Interpretive Social Criticism and the Ends of Social Justice
}

\author{
Andrew Gibson, McGill University
}

\begin{abstract}
The article lays down the broad strokes of an interpretive approach to social criticism. In developing this approach, the author stresses the importance of both a pluralistic notion of social justice and a rich ideal of personal growth. While objecting to one-dimensional conceptions of social justice centering on legal equality, the author develops the idea of there being multiple "spheres of justice", including the spheres of 'care' and 'merit'. Each of these spheres, he argues, is subject to historical interpretation. He furthers this view by arguing that the social basis for these different spheres is best understood against the canvas of an ideal of self-fulfillment and individuality. Based on the elaboration of these two sets of premises - a pluralistic conception of social justice and a collective ideal of personal self-fulfillment-the article outlines the basis for and challenges inherent to the practice of interpretive social criticism.
\end{abstract}

\section{Introduction}

Just recently, while talking with some of my university colleagues, I attempted to come up with a defense of free post-secondary education. Running short on arguments about how lower tuition means greater accessibility to more Canadians, I spontaneously mentioned something about how education strengthens the social fabric and increases general well-being. A rebuttal then came from one of my colleagues, who, with great enthusiasm, claimed that education is only worth supporting because it permits "insurrectionary activity, procrastination, revolt and random displays of poetic terrorism". While taking the comment with a grain of salt, I was reminded of the palpable confusion that presently reigns in the university world with regard to the rationale behind social criticism.

It is tempting to link the confusion surrounding the practice of social criticism to changes in the political landscape that came about in the late 1980s, after the fall of the great ideological divisions of the post-war period. My feeling, however, is that the problems of social criticism run deeper than this. The big issue has to do with the way in which university intellectuals relate to the morality and politics of the people they are criticizing. Of the various critical programs and approaches that we see in the humanities and social sciences today, there exist important discrepancies between what is being thought up by professors and students, on the one hand, and the lived experience of the everyday morality on the other.

The move towards 'subversive' and 'transgressive' intellectual contestation so popular on campuses in the 1990s is an example of the type of gulf I am talking about. While widespread in some university departments, its oppositional esoteric vocabularies have limited application 
outside the university environment. ${ }^{1}$ There is a different sort of critical approach, however, that also contributes to maintaining the gulf between intellectual labour and the democratic unfolding of a country's everyday morality and political life. This is the prestigious area of philosophy known as 'normative critique'. While the purpose of this paper is to outline the basis for a socially contextualized, interpretive approach to social criticism-one that is less detached and formulaic than normative critique, and thus more attuned to the plural and contradictory aspects of the historic morality of specific communities - the article proceeds in this task by first casting an eye on the shortcomings of the normative approach.

In looking at the normative approach, I use the influential work of Jurgen Habermas as a focal point. There are other prominent philosophers who are much less attuned than Habermas to the social contexts of moral expression and political organization. Consider for example Richard Dworkin's emphasis on de-contextualized "abstract justice" or John Rawls' appeals to morality as it emerges from behind an ahistorical "veil of ignorance". Habermas is, indeed, perhaps one of the more empirically-sensitive philosophers of justice. And yet it would seem that even he succumbs to the pull of a universalistic, one-dimensional theorization of the moral world. When he is theorizing in this mode, he cannot but distance himself from the way in which people relate to the ideals and injustices of their respective political communities. ${ }^{2}$

The interpretive approach to social criticism sketched below is largely a rehearsal of ideas put forth by other scholars-most importantly, perhaps, the American philosopher Michael Walzer and the German critical theorist Axel Honneth. Their ideas are put together here in such a way that a particular kind of interpretive critique is brought to light. If we take social criticism, generally, to mean critical insight directed towards cultural affirmation, elaboration and betterment, its interpretive form can be understood as a matter of developing such insight based on the moral sensibilities and practices which have already gained a foothold in a specific time and place, in a specific country or "community of experience".

In the second part of the paper, I argue that instead of singularly focused, one-dimensional theorizations of social justice, we need to develop an historical, pluralistic view that starts from the premise that any one society will encompass a diversity of moral dispositions - what Walzer (1983) calls multiple "spheres of justice". This fits nicely with the complex formulation that Honneth gives to the notion of social justice. In his reformulation of some old Hegelian themes (1995, 2003, 2006), Honneth sketches a broad yet historically specific interpretation of social justice involving not only the sphere of legal equality, but two other moral spheres as well — that of labour based 'merit' and that of the more privatized morality of 'care'. One of the premises of the paper is that the scholarly interpretation of these different spheres of social life should form part of the bread and butter of social criticism. Yet the manner of their historical patterning also suggests that social critics might do well to look to the greater purposes and goals that the morality of these different spheres can be understood to facilitate.

In liberal democracies, one such purpose is frequently glossed as that of personal freedom or individual autonomy. The aspiration being referred to here is, I argue, best understood in terms

\footnotetext{
${ }^{1}$ Richard Rorty (1991) provides an interesting, if schematic summary of an approach he caricatures as that of "advanced literary theory".

${ }^{2}$ Habermas is also the author of excellent "journalistic" work. See for example his Sur L'Europe (2006), Une époque de transitions (2005) and his "Crossing Globalization's Valley of Tears" (2000). Interestingly, the orientation of this work feels almost like the opposite of his normative philosophy.
} 
of an ideal of 'personal growth' or 'self-fulfillment'. Stanley Cavell (2004) describes it as an ideal which centers on the discovery of what a person is made of and on the cultivation of what that person is "meant to do, or to be" (p. 446). The ideal has been worked out in a fairly comprehensive manner in the literature on the romantic notion of "authenticity" (Trilling, 1972; Taylor, 1991; Nehamas, 1999). This is not to say that it is an ideal that is simply accepted without contestation. It is considered, for example, to play an important role in the motivational basis of contemporary consumer society (Campbell, 1987; Illouz, 1997). Still, it would seem that much of this contestation is directed toward debased forms of authenticity and not toward debunking the ideal itself. Even the relentless criticism of Michel Foucault (1984) calls attention to the promise of authenticity, or "care of the self".

The point of referring to authenticity is to show the important interplay between this personal growth ideal and the different spheres of justice, insofar as the latter may be understood as preconditions to the former. In the third section of the paper, I say a little more about what is meant by this ethics of personal growth. At the same time, I paint a rough picture of how such an ethics might be defended as a collective project within the context of liberal democratic states. This requires balancing off liberalism's 'political neutrality' with the institutional structures that citizens of liberal democracies have historically sought to provide for themselves, as means to maximizing the possibilities of self-development and full individuality. In the last section of the paper, I return to the more practical aspects of interpretive social criticism. While emphasizing the importance of the social immersion and connectedness of the critic, I fend off the charge of critical circularity that is often held against interpretive critique.

\section{Problems of Relevance and Breadth}

What may be seen as a current of cynicism in academia, perhaps even in society at large, has led to an abandonment of grand, utopian narratives. This being said, there still remain forms of social critique that hold horizons of collective betterment as their measure. We see some such critical programs in social science departments, but given the developmental path of sociology and other social scientific disciplines, it is difficult for such programs to come up with critical evaluations that go much beyond suggestive empirical description. ${ }^{3}$ As a consequence, social criticism is often confined to debates within philosophy departments. The problem with this, if we're to believe Walzer's (2002) caricature of the critic who has left the cave to go and ponder after truth on the philosopher's ledge, is that philosophical forms of critique seldom take seriously the moral orientations developed throughout the history of specific communities.

\footnotetext{
${ }^{3}$ Such empirical descriptions are, of course, invaluable indicators of what is going in large-scale societies, but their moral and political significance is not always obvious, neither to the sociologist, nor to the relevant political community. As Adam Swift (2004) notes, many sociologists "regard what they do as relevant to matters of social justice in general, and of equality of opportunity in particular. They often acknowledge that their research is motivated, at least in part, by a normative interest in such matters. But that interest tends to be rather vague and diffuse. Masters of precision when it comes to measuring and analyzing the empirical phenomena they study, they are, typically, less sure in their analytical control of concepts such as 'equality of opportunity' or 'life-chances'. Moreover, they are sometimes suspicious of attempts by others to treat normative issues with similar seriousness, holding - less or more consciously - that such issues are not amenable to intellectually respectable investigation" (p. $1)$.
} 
Inquiries into the nature of "justice-in-itself" that aim to elaborate a set of universally applicable moral rules are, according to Walzer, not likely to hold much sway beyond the intellectual milieu in which they are thought up.

Keeping Walzer's contention in mind, I want to briefly look at Jurgen Habermas's "philosophical anthropology", as I believe that it shares some of the same problems. The goal of most forms of philosophical anthropology is to bring together different genres of academic inquiry in such a manner as to offer a set of coherent and convincing arguments about human nature (Honneth \& Joas, 1988). This is undoubtedly an important exercise, if for no other reason than to debunk one-sided assumptions about "the way humans are", which are often carried into the political arena and which serve to back this or that policy initiative. But the problem that besets this form of inquiry from the start is that it is notoriously difficult to substantiate any kind of human nature argument whatsoever (Honneth, 2007). And we can assume that this is doubly the case for arguments that have as their aim a deep set of political reforms.

The understanding that Habermas $(1984,1990,1998)$ has of his research on the "pragmatics of communication" has brought him to question the democratic conditions of free and fair public debate. The basis of his critique rests an image of human nature that is fundamentally linked to our capacities as language-users. To summarize crudely, his position holds 1) that there are pragmatic presuppositions which language-use entails and 2) that we must respect these if we are to live up to the inbuilt standards of human sociability. Habermas's portrayal of the social dynamic that these language-based presuppositions entail can be glossed as the unconstrained exchange of "validity claims".

In laymen's terms, the argument claims that the anthropological foundations of language-use point the way to an ideal configuration of public debate in which every individual is able to freely express their opinion on matters of common concern. Habermas reasonably assumes that more just modes of public debate will bring about more socially just societies. On the basis of his anthropology of language, Habermas posits the need for substantial political reforms in decisionmaking processes, which he believes will lead to a substantial revision of commonly accepted norms and practices. Such predictions notwithstanding, the study of the pragmatics of human language-use allows Habermas (1990) to postulate the following moral maxim: that "every valid norm must satisfy the condition that all affected can accept the consequences and the side effects its general observance can be anticipated to have for the satisfaction of everyone's interests (and these consequences are preferred to those of known alternative possibilities)" (p. 65).

This prescriptive formulation is an eloquent one and it has indeed been seductive for a large, if mostly Western, intellectual audience. Of course, the implementation of any such view is really only conceivable in democratic societies. And even in the most democratic of actually existing democracies, the policies stemming from such a proposal would be considered quite radical. My point is not that such a program of reform should be dismissed because of how radical it is. Nor is it to say that Habermas' "discourse ethics" is without historical grounding in Western democracies. Rather, I am simply making the (perhaps trivial) point that the political relevance of any such program is not likely to stem from appeals to tenuously far-reaching anthropological claims related to universal criteria of human conduct. For the likelihood that any such relevance will be gained is highly dependant on the argument being made in a vernacular that speaks to the shared understandings of a particular political community (Walzer, 1993, 2002; Rorty, 1998). This would, in turn, require drawing persuasive links between the aims of free and fair public 
debate, and the repertoire of moral sensibilities and practices that are already part of the social fabric.

If taken as a form of social criticism capable of addressing the full scope of social injustices, Habermas' approach suffers from another kind of weakness. The moral core of his contribution, which essentially requires that each person affected by a collective decision be in equal acceptance of it, emerges from a one-dimensional conception of social justice. It is onedimensional in the sense that it limits itself to a singular view of justice centering on a notion of equality as equal treatment. Habermas's 'ethical formalism' shares this limited egalitarian focus with other prominent schools of thought. The utilitarian logic of the greatest happiness for the greatest number, for example, also suffers from a restrictive egalitarian thrust coming from the central emphasis it places on the equal dignity of each person. The intuitive core of each of these dominant approaches to moral thought is, as Taylor (1985) puts it, that "everyone ought to count and all ought to count in the same way" (p. 231). ${ }^{4}$

It is no secret that there is this sort of egalitarian emphasis in Habermas' discourse ethics, as well as within his broader critically oriented anthropology of human communication. Without trying to account for the motivation behind this style of egalitarianism, it seems fairly clear that if his approach were more society-specific and historical in character it would have to account for a wider breadth of moral sensibilities and practices. The discourse ethics approach provides the possibility of leaving each historically situated democracy to sort through this moral morass on its own terms - as long as it does so by way of the unconstrained exchange of validity claims. But this presumes that one can separate out the area of human communication as the linchpin of moral concern. It also presumes, as I have been arguing, that this linchpin is subject to both authoritative intellectual prescription and moral universality.

Certainly, there is a kind of intellectual intensity that is brought about through resolutely focused approaches to social justice. And when one considers the scandalous discrepancies that exist between the highly defendable ideal of equal treatment, on the one hand, and the manner in which certain groups and individuals are actually treated on the other, it is obvious that there is much work to be done. Still, the perspective taken here is that social injustices are best addressed, not by appeal to overly abstract one-dimensional theories of justice focusing solely on equal treatment, but rather by appeal to the diverse moral standards and shared collective purposes that citizens hold in common. Before being able to persuasively appeal to these, the critic must of course have an idea of what these in fact are. I have mentioned the collective ideal of personal self-fulfillment, but have not yet expanded on the moral understandings and practices that we might see as facilitating this ideal. ${ }^{5}$

\footnotetext{
${ }^{4}$ Taylor's point is that each of these theories has a tendency to reduce the complex plurality of the moral world to a one-dimensional variation of moral universality. He argues that "one of the big illusions which grows from either of these reductions is the belief that there is a single consistent domain of the 'moral', that there is one set of considerations, or mode of calculation, which determines what we ought 'morally' to do . . . We could easily decide that the universal attribution of moral personality is valid . . . but there are also other moral ideals and goals . . . which cannot be easily coordinated with universalism, and can even enter into conflict with it" (1985, p. 233).

${ }^{5}$ There are, of course, many ways in which the purpose of self-fulfilment is supported and sustained in liberal democracies. While the paper focuses on three different spheres of justice, I am not making any claims about these being the only relevant spheres, or about them being "systematically" related to an ideal of personal growth.
} 


\section{Equal Treatment and What Else?}

I will say more about the morality of equal treatment below, but I first want to draw a contrast between this moral domain and another, which until recently has drawn much less attention. This contrasting realm of moral practice exists at what sociologists call the "micro" level of social interaction - in those seemingly unorganized moments of interaction between friends and loved ones. I am referring here to the moral outlook which has taken root over the last several centuries with the institutionalization of a privatized domain suited to modern family life. There is a distinctive moral sensibility at the heart of this realm of activity that has often been passed over in liberal egalitarian conceptions of social justice, where the focus is on each man and woman being treated with the same anonymous principle of equality.

Feminist scholars have, in recent decades, done the most to describe the precise nature of the sensibility that is woven into private relations of intimacy and family life. ${ }^{6}$ An affectionate morality of "care" has since been taken as the guiding sensibility of domestic life-that cherished private realm which has come to exist in juxtaposition to the instrumental demands of public life. In the caring environment of the family, the romantic partner, child and parent will each have their own unique set of vulnerabilities, needs and wants. The morality of equal treatment is not sufficient to meeting these highly personal demands. The moral feelings that guide this social realm move, somewhat oppositely, in the direction of a type of differential treatment requiring that attention be paid to the idiosyncratic needs and irreplaceable characteristics of the "concrete other" (Benhabib, 1986; Baier, 1994).

There are fairly straightforward links that can be made between this caring form of justice and the personal growth ideal mentioned above. Ever since the middle of the $18^{\text {th }}$ century, the affectionate ties of marriage and family life have been increasingly protected from public demands of a more impersonal sort (Ariès, 1962). The historic upshot has been the organization of a realm of social life infused with the supportive heightening effects of romantic and familial love. It is a realm where childhood has come to be lived out freely, in a largely self-exploratory manner, away from the burdens of toil. It is also a realm in which marriage, or romantic couplehood, has come to be lived out with greater equality and emotional freedom. ${ }^{7}$

The developmental history behind the emergence of this realm of caring activity overlaps in many ways with the history of struggles for social justice. Take for example the succession of $19^{\text {th }}$ century campaigns that aimed to alleviate children form the duties of labour, or later campaigns to reduce the number of working hours for adults in the hope that private relations would become a meaningful part of the social life of all citizens (Parr, 1982). There have also been the various feminist waves that sought to free women from the constraints of domestic labour and from the limiting role-expectations that went along with this (Luxton, 1980). It is only

\footnotetext{
${ }^{6}$ The issue of this unacknowledged moral register was first brought to light in the Kolhberg-Gilligan debate in developmental psychology. Carol Gilligan (1982) made the argument for a distinctive yet largely neglected form of moral expression, which she, at first, thought to be more prominent in women. Regardless of the psychological validity of her original findings, the door had been opened to another moral dimension, the importance of which has since been emphasized by feminist political thinkers, such as Benhabib (1986) and Baier (1994).

${ }^{7}$ Stanley Cavell (1981) offers a stimulating analysis of how this newfound freedom was exemplified in Hollywood movies from the 1930s and 1940s.
} 
in gradually liberating themselves from these patriarchal cultural expectations that women could imagine fully partaking in the expression of their personal needs and wants.

This historical snapshot opens a window onto a moral realm that is often overlooked in hyper egalitarian conceptions of social justice. In addition to the important differences that exist between the morality of equal treatment and that of care, I want to draw yet another contrast with the 'morality of merit'. The distinction may be less obvious at first, since the registers of merit and equality are both institutionalized at the "macro" level of social interaction. Both forms of moral expression are woven into the cultural fabric of large-scale institutions, such as bureaucracies, legal systems and markets. ${ }^{8}$ There are, however, fundamental differences between the two. While equality is woven into the practices of democratic citizenship, merit is as Parkin (1971) and Parsons (1971) argued some time ago, a moral standard which is part and parcel of the occupational division of labour.

Citizenship has to do with the way in which each person lives out their rights and responsibilities as a member of a self-governing polity. Merit, on the other hand, pertains to the contribution in labour that each individual makes to the collective. The major, if paradoxical, difference between the two forms of moral expression is that while the first stems from a fraternal equality between citizens, the latter implies felt differences of worth between these same men and women (Dubet, 2006). It will likely be fairly straightforward to convince the reader that the fraternal bonds of citizenship are pertinent to the building of a more socially just society. This fraternal ethos is commonly thought of in terms of $20^{\text {th }}$ century attempts to institute a basic set of "social rights". The underlying rationale for securing these sorts of rights is that all citizens, as participants of a common democratic project, should be provided with the cooperatively instituted means to material security and social opportunity (Marshall, 1950).

In a similar manner, it might be argued that the project of securing social rights for each and all is both a 'means' and a 'due' for collectively sustaining just and democratic social conditions (Taylor, 1985, chapter 11). There are also other ways of picking up the thread of collective selfunderstanding that is manifest in expressions of moral equality. After the Great Depression and into the post-war period, the institutionalization of social rights was, as Canadian historian James Struthers (1983) describes it, a matter of expressing group solidarity in the face of the vagaries of the market. If we return further back in time to the period of the Canadian Enlightenment we find yet another strand of the egalitarian ethos.

In the first quarter of the $19^{\text {th }}$ century, the equality question was debated as a matter of "intellectual equality" in public life. The argument which won the day was that it was not only those few that the monarchy selected for office which had "the capacity to judge" (McNairn, 2000). Rather, it would eventually come to be seen that all citizens had the capacity, or at least the potential, to partake fully and responsibly in public life. This collective realization can be taken as a bridging point connecting the call for greater equality with the fastening of a foothold for the romantic ideal of personal growth. Such a bridge was significant in that it provided an important steppingstone towards dignified self-presentation in public life. Increasingly, men and women would, in conversation with their peers, be able to cultivate what they were to make of themselves as freethinking individuals.

\footnotetext{
${ }^{8}$ Jeffrey Alexander's (2003) "cultural sociology" offers a comprehensive grasp of the complex ways in which seemingly invisible "cultural structures" are woven into societal institutions and practices.
} 
As mentioned above, the links between social justice and the egalitarian dimension of the everyday morality will surely seem obvious enough. What is likely to be more problematic is the manner in which the morality of merit can, it too, be understood to have a place in the landscape of social justice. We can link such reticence to a tension within the morality of merit itself. It is on the one hand a form of moral expression which demands that fellow citizens be recognized for the work they accomplish within the context of a cooperative political community. On the other hand, the more specific understanding at play is that some forms of work are worth more than others and need to be recognized as such. What comes about with this register of collective understanding, then, is a hierarchy of worth.

It is not impossible to imagine a future society in which any such monolithic hierarchy of worth has ceased to exist. ${ }^{9}$ From a contemporary perspective, it is plausible to conceive of the particular shape this hierarchy has come to assume as the outcome of a series of emancipatory steps forward. We can only grasp things in this light, however, by comparing the current hierarchy with that which came before it. To get a rough sense of this, we must look to the social life of medieval Christendom, which was also made up of a hierarchy of worth, albeit of a radically different sort. There isn't the space to get into the manner in which this hierarchy was set up, except to say that it was based on a highly complex system of orders, ranks and titles, which were fixed by birth and blood but were also tied into an entire cosmological worldview (Lovejoy, 1957).

In the $17^{\text {th }}$ and $18^{\text {th }}$ centuries, this cosmological outlook took root on the shores of New France and British North America (Miquelon, 1987; Burley, 1997). But just as in Europe, this age-old cultural structure was beginning to shift and change under the pressures of modernity. With the profound and enduring influence of the democratic revolutions of the late $18^{\text {th }}$ century, along with trends in industrialization and urbanization, the Christian hierarchy of worth would eventually be so radically transformed as to give birth to a new moral order. The key element of this new order was that one's overall social status was to be tied to the sort of life one led and, more specifically, to one's efforts and contributions in this-worldly, productive activity.

The process can be taken as one in which the question of where one stood in the eyes of others came increasingly within the sphere of one's own power, in the sense of resulting from one's own efforts and abilities. As such, one's social standing was progressively loosened from the grip of outside factors such as social lineage, nepotistic relations and property assets. At the same time, higher forms of social standing, which have always been covetously guarded by the elite, were, with the turn of the $20^{\text {th }}$ century, broadened to include a wider spectrum of occupations (Keller, 1963; Hartmann, 2007). This isn't to say that the new hierarchy stopped pitting the worth of some groups and individuals against that of others, but rather to say that any such hierarchy was increasingly subject to democratic pressures and influences.

\footnotetext{
${ }^{9}$ Walzer elaborates such a position in his Spheres of Justice. He speaks of multiple hierarchies of worth, where none would be predominant over others. In such a situation of "complex equality", there would as he puts it be no more BMOCs ("Big Men On Campus").

${ }^{10}$ In referring to this broadly Western historical process, Honneth (2003) notes that "the extent to which something counts as 'achievement', as a cooperative contribution, is defined against a value standard whose normative reference point is the economic activity of the independent, middle class, male bourgeois. What is distinguished as 'work', with a specific, quantifiable use for society, hence amounts to the result of a group-specific determination of value - to which whole sectors of other activities, themselves equally necessary for reproduction (e.g. household work), fall victim" (p. 141).
} 
It is important not to exaggerate the magnitude of such influences. For there were democratic injustices in the very occasions through which a new schema of worth was being progressively worked out - injustices in impressing upon the public mind which people and professions would be worth what. ${ }^{10}$ Still, the injustices were themselves to become the subject of historic contestation. If we consider that the single most important indicator of social worth is the remuneration that individuals receive from their employment (Swift, 1995; Honneth, 2003), then the history of collective bargaining for higher wages becomes an important instance of a meritocratic struggle for social justice. The politicization of domestic labour, though more complicated, can also be understood as a struggle against an abysmal lack of social merit. ${ }^{11}$

Returning now to the ideal of self-fulfillment and individuality, there are some important parallels to be made between it and the merit sphere of activity. While the mastery of an occupation or pursuit of a career is but one avenue through which men and women may find an avenue of fulfillment, it is nonetheless a socially predominant one. It is of historic significance that each person today is in principle free to choose which occupation they should like to learn and practice. Such life changing choices are of course not easy ones to make. An excellencebased hierarchy of publicly recognized worth may help to confirm, guide and inspire individuals in their choices. This does not preclude the need for equalizing democratic pressures concerning the nature and degree of differences in worth. Rather, it in fact reinforces it. For it is essential, in light of the diversity implied by the very idea of individuality, that men and women have access to a broad base of rich and rewarding fields of work.

I have been arguing in this section that social justice must encompass more than the sphere of justice as equal treatment. There are other types of sensibilities and practices which have had profound effects in recent centuries and which have led to the development of multiple, mutually irreducible spheres of justice. This argument takes for granted that such ideals developed within the context of nation-state communities. It is certainly relevant to question whether moral sensibilities are not in fact much more flexible and pluralistic than suggested by any notion of a homogenous national community. This is especially true given current global trade and immigration patterns. But as much as national communities in Europe, for example, are beginning to open onto one another, there are persuasive accounts which suggest the nation-state still functions as the primary, if "banal" nexus of political socialization (Billig, 1995; Kupchan, 1995). From the standpoint of social criticism, it is fruitful to conceive of each of the spheres of justice discussed above in relation to the support they provide for the romantic ideal of personal growth. But stating things in this manner poses the question of the extent to which it is in fact desirable to conceive of political reforms in relation to an ideal of human development - what is known in political theory as an ideal of the good life.

\footnotetext{
${ }^{11}$ Without equating domestic labour with non-domestic forms of gainful employment, a strong argument gain can be made for considering the historical devaluation of women's work, both inside the home and in the public realm, as variations on the theme of meritocratic injustice (Rossler, 2007).
} 


\section{"Human Development in its Richest Diversity"}

The standard position among defenders of liberalism is that states should never get involved with the promotion of any particular mode or style of living on the pretension that it is better than others. Rather, political communities should be neutral with regard to the way in which individuals choose to lead their lives, at least with regard to state legislation. So long as particular styles of life are not harmful to others, the state should have nothing to do with the ends that individuals choose to pursue. The rationale behind this position of 'political neutrality', which has flowed historically from the position of religious tolerance, is that any such stateinterference risks opening the way to violent oppression. ${ }^{12}$ The $16^{\text {th }}$ century Wars of Religion are an historic case in point. More recently, nationalistic versions of "the good" have tended to pit one ethnic mode of life against another, often with disastrous consequences.

Even when conceptions of how individuals should best lead their lives assume more seemingly benign forms, such as the deliberative citizen engaged in collective decision-making processes, defenders of political neutrality caution against it. Aside from the danger of slippage towards greater manifestations of state-based authority, there is also the danger of paternalism, that among the diversity of purposes that individuals may hold, the promotion of any particular one will undermine the happiness of those men and women who simply do not share it. As Ronald Dworkin (1993) argues, "no life is a good one lived against the grain of conviction. It does not help someone else's life but spoils it to force values upon him he cannot accept but can only bow before out of fear or prudence" (p. 168).

Many critics today argue that neutrality and "tolerance talk" can be pushed too far, such that the excesses of the doctrine begin to mandate new forms of intolerance and state-based coercion. ${ }^{13}$ Others argue that neutrality is but a cultural artifact - that liberal democracies cannot avoid promoting a particular, if loose knit conception of the good life. The position taken up here is that there is indeed a moderate manner in which Western democratic states should rightly be understood as promoting the good of a particularistic form of life. Honneth and Anderson (2005) describe this as state endorsement of a "weak idea of the good". The 'weak idea' they are referring to is that of an 'intersubjectively' enhanced notion of individual autonomy. This, in turn, has much in common with the ideal of self-fulfillment referred to above.

Contrary to what might be assumed, the 'weak' criterion does not refer to the habit that most Western democracies have of routinely excluding the less privileged of their members from the hope of an autonomous existence. It refers, rather, to the fact that even the most egalitarian state can only go so far in promoting the way of life in question. For one of the very premises of autonomous self-fulfillment is that it can take shape in a great diversity of forms. It is true that at the heart of this way of life there lies an ethics of personal cultivation that opposes "ascribed" and "conformist" lifestyles. But there is nothing in the way of a detailed program as to how this cultivation should be pursued, nor is there any predetermined notion of what such cultivation will amount to for any one individual. Certainly, there are men and women who serve as admirable examples of such a mode of life, whether in the mastery of a field of human activity or

\footnotetext{
${ }^{12}$ The founding text here is perhaps John Locke's (1689) A Letter Concerning Toleration.

${ }^{13}$ See, for example, Wendy Brown's (2006) study of the excessive rhetoric of tolerance and its implications in domestic and international contexts.
} 
the fashioning of a strikingly original selfhood. But any one of these examples will likely only be admirable in the eyes of a particular kind of person or audience (Nehamas, 1999, chapter 4).

In a sense, then, the most we can say about this particular mode of the good life is that it must be discovered for oneself. But if this is the case, the question then becomes: how can the political community get involved in supporting this mode of life without simultaneously undermining the premise of self-discovery? Without getting into the details of this paradox, one can argue that the answer lies in the requirement that the state only ever promote this way of life to the extent of ensuring the conditions needed to make it a real opportunity for each and all (Honneth \& Anderson, 2005). This would, among other things, require attending to the moral adjudication of the different spheres of justice - of, for example, care in the family, equal treatment under the law and merit in the world of work. As long as greater social justice is sought after in the organization of the different moral spheres, then the question of whether and how the life of personal growth is pursued need not be anything more than a matter of private concern.

The cultural aspiration behind this way of seeing things - the aspiration, that is, towards "human development in its richest diversity"-is not something that is entirely new. ${ }^{14}$ If it is an aspiration that we can agree is at the heart of many of our liberal democratic institutions - from the nuclear family to the institutionalization of the idea of 'careers open to talent', from the fundamental freedoms to the flourishing of the arts, from the welfare state to the universal education system - then it is also something that social critics must be attuned to in speaking of the deficiencies and injustices of their respective societies. But how exactly should the interpretive critic go about speaking of such an aspiration and of the conditions present or lacking in the different spheres of justice? How, in other words, should she understand the art of her own practice?

\section{Social Criticism in an Interpretive Mode}

I began the paper by suggesting that one way of lessening the confusion surrounding social criticism would be to move away from overly abstract, one-dimensional approaches to the problem of social injustice. I mentioned that interpretive criticism constitutes just such a move, for it calls on social critics to look to the history and to the full breadth of contradictory tendencies in the everyday morality that permeates their respective political communities. Such an interpretive exercise requires coming to terms with the pluralistic moral sensibilities that infuse collective practices. This exercise will be met with greater success, I have been arguing, if it also pays attention to the more encompassing purposes that citizens share in common, such as the self-development ideal mentioned above. ${ }^{15}$

While these moral sensibilities and collective purposes may well constitute the bread and butter of social criticism, I have yet to say anything regarding the manner in which critics can be

\footnotetext{
${ }^{14}$ John Stuart Mill uses this phrase, which he burrows from the Prussian linguist Wilhelm von Humboldt, as the epigram to his famous On Liberty.

${ }^{15}$ Certain other collective purposes shared by Canadians are what might be described as more immediately social in nature. Consider, for example, the aspirations behind the "multicultural mosaic". Charles Taylor (1993) offers a powerful account of the relevant sense of collective purpose by outlining the potential of a "deep diversity", by which he means a social diversity that enables multiple modes of civic belonging.
} 
understood to proceed in their interpretations. The first thing to consider in this regard is what Walzer (1993) identifies as the requirement of "closeness" or "social connectedness". This seemingly commonsensical requirement is that a proper interpretation of moral sensibilities and purposes must be based on an intimate knowledge of their particular social meaning and texture. This requires rich insight of an historical or sociological sort into how the different moral understandings have developed, or even somehow failed to develop. It also requires a lived appreciation of what these understandings can mean in the context of a specific society.

A second element of interpretation, which can really only stem from social connectedness and attachment to a common way of life, is a capacity for 'prophetic idealism' - the critic's ability, that is, to call upon social changes of a morally and politically progressive sort. Now, in order to properly situate this issue of prophetic idealism, I want first to grapple with the main charge that is laid against interpretive criticism: the charge of critical circularity. Simply put, the claim is that interpretive criticism is too close to the political fray, such that it will inevitably fail to gain the critical distance required to provide a non-redundant critique of the current social order.

It is easy to grant that the social critic can be too close to the political fray, to the point of being unable to offer a properly critical perspective. Typically, what this will mean is that the critic is too close to certain types of relationships, too close to the seats of political and economic power. This kind of proximity would certainly make it more difficult to see society whole. As Walzer (1993) puts it, the "actual wielding of power and the Machiavellian ambition to whisper in the ear of the prince... are real obstacles to the practice of criticism, because they make it difficult to look with open eyes at those features of society most in need of critical scrutiny" (p. 60). But this practical issue has in fact little to do with what is really meant by the charge of circularity. For what is usually being referred to is a different sort of blindness, coming not from egoistic selfinterest but rather from the lack of an external viewpoint.

The worry is a fairly straightforward one, as expressed by Dworkin (1983) and then more pointedly by Cohen (1986). If the critic is supposed to assess the question of social justice on the basis of ethical standards and practices that are already in existence, then how can the outcome be anything other than a condoning of the status quo? Cohen poses the problem more acutely by confronting Walzerian interpretive criticism, which he sees as inherently "communitarian", with a fundamental dilemma. This "simple communitarian dilemma" arises with the interpretive predicament of having but two methodological options for gaining critical leverage: gleaning collective values from existing practices, or gleaning them form the stories we tell of ourselves and then applying them to social practices.

The dilemma is seen to arise because of the redundancy of criticizing the status quo on the basis status quo values, on the one hand, and from a problem of proof of evidence on the other (the problem here being that it is impossible to know which concrete ethical standards are carried in the stories we tell of ourselves). The way out of this dilemma requires an argument supporting the very existence of such things as common sensibilities and shared understandings. It also requires an argument about how we can move towards greater comprehension of the shape and substance of such diffuse cultural formations. Finally, it requires an argument for how there inheres within the spectrum of shared understandings a "surplus of validity" that reaches beyond the status quo.

I do not have the space to defend the sociological claim that citizens of liberal democratic states share certain moral understandings in common. It will have to suffice to say that, while we rarely come upon uncontested terrain as to what these understandings actually are, it is quite 
plausible to assume a spectrum of meanings, if only in the framing of recurring public debates, that are more or less representative of a particular political community. There need not be a consensus regarding these common understandings. For the condition of there being either consensus or cleavage is, as Taylor (1985) argues, "a certain set of common terms of reference" (p. 36). Still, the possibility of effective social criticism requires that the critic take a step further onto this interpretive terrain and identify, among these terms of reference, those which are most representative of the community in question-those, that is, which the community would consider to be its finest, most admirable qualities (Walzer, 1993).

This move will inevitably be political in nature, in the sense of being subject to the sensibilities of Left and Right. For this sort of politicization is an inevitable part of the practice of social criticism in modern democratic contexts. There can be no final "objective" critical intervention that will reconcile all differences within the pluralistic spectrum of collective meanings. What we see, rather, is a consistent yet diffuse and evolving set of meanings. And it is within such historical continuities of meaning that there inheres a "surplus of validity" or "validity overhang", which points towards the shared standards and collective images needed to move beyond the status quo (Honneth, 2004). Once a political community's finest, most admirable qualities are critically portrayed, whether with reference to practices, traditional stories or other moral artifacts by which a society would do damage to itself to disavow, it then becomes possible to persuade those in power of the need for reform in those areas of social reality which betray those very same qualities.

Such a betrayal might have sources in changes to the institutional structure of a society. Consider, for example, the prospect of a country whose occupational institutions have been incrementally transformed such that the conditions of working life are no longer rewarding, not even for well-to-do middle and upper class professionals. More to the point, however, with regard to social injustices suffered by specific groups and individuals, the betrayal may be "cultural" in origin. ${ }^{16}$ By this, I mean that the gap between collective standards and the lived experience of social reality can be traced back to a hypocritical, moral lopsidedness. Taken within the context of plural spheres of justice, moral lopsidedness looms when one dimension of the social morality comes to degrade or undermine another. ${ }^{17}$ With respect to the spheres of care, equal treatment and merit, this slippage would constitute a betrayal of the moral logic of the spheres themselves, but also in the sense that the wearing down of any one sphere would stunt the social hope of human development and romantic freedom.

\footnotetext{
${ }^{16}$ Honneth (2006) picks up on this distinction with reference to two different genres of social criticism: one linked to the diagnosis of civilizational "pathologies" and the other to the identification of changes linked to social injustices.

${ }^{17}$ Walzer (1983) describes this as a process of "invasion", where the agents of authority and argumentative tactics of one sphere invade that of another.
} 


\section{Conclusion}

The article sketches a framework for a mode of social criticism that has not yet been sufficiently accounted for in the humanities and social sciences. The very premises of this interpretive form of criticism call into question the divergences that currently exist between the university milieu and the everyday world of morality and politics. The article begins by alluding to the withdrawal of the "postmodern" critic into an esoteric campus politics. It then turns to the normative approach of Jurgen Habermas' critically oriented philosophical anthropology. I note, first, that his universal discourse ethics, while tenuously far-reaching in its empirical claims, tends to distance his critique from actually existing moral sensibilities, thus depriving it of much of its political relevance.

Habermas' approach falters in another sense insofar as it fails to account for the breadth and plurality of moral expression in the Western world. Indeed, given his discourse ethics methodology, Habermas makes no attempt to account for the relevant diversity of moral standards that exists in, for example, Germany, Canada and most other Western democracies. The second part of the paper juxtaposes the morality of equal treatment with two other spheres of justice, those of 'care' and 'merit'. This provides a window onto the historical dynamics that have come to shape these different spheres. I draw affinities between each of the spheres by situating them within the context of a collective ideal of human development and self-fulfillment. In the third part of the paper, I suggest that this loose knit personal growth ideal can be defended as a way of life fit to liberal democracies.

Finally, the last section addresses the method and manner of interpretive social criticism. I pick up on the importance of the social immersion and connectedness of the critic and on her capacity for prophetic idealism. While I emphasize the need for a degree of critical distance from the political fray, I argue the importance of there being a close relation to the moral culture of the relevant political community - if not a closeness to its "core values" then at least to its common terms of reference. It is by interpreting such common reference points that a "validity overhang" rises to the fore. By defending this view, I am also able to defend the coherency of the interpretive approach against the charge of circularity. This allows me, finally, to discuss the implications for the critic of there being different forms of validity relevant to each of the different spheres of justice. 


\section{References}

Alexander, J. C. (2003). The Meanings of Social Life: A Cultural Sociology. Oxford: New York: Oxford: University Press.

Ariès, P. (1962). Centuries of Childhood: A Social History of Family Life. New York: Vintage Books.

Baier, A. (1994). The Need for More than Justice. In A. Baier. (ed.), Moral Prejudices (pp. 18-32). Cambridge: Harvard University Press.

Benhabib, S. (1986). The Generalized and the Concrete Other: The Kohlberg-Gilligan Controversy and Feminist Theory. Praxis International, 5(4), 402-424.

Billig, M. (1995). Banal Nationalism. London/Thousand Oaks/New Delhi: Sage.

Brown, W. (2006). Regulating Aversion: Tolerance in the Age of Identity and Empire. Princeton, N.J: Princeton University Press.

Burley, E. (1997). Servants of the Honourable Company: Work, Discipline, and Conflict in the Hudson's Bay Company, 1770-1870. Don Mills, Ontario: Oxford University Press.

Campbell, B. (1987). The Romantic Ethic and the Spirit of Modern Consumerism. Oxford, UK: New York: NY: USA: B. Blackwell.

Cavell, S. (1981). Pursuits of Happiness: the Hollywood Comedy of Remarriage. Cambridge, Mass: Harvard University Press.

Cavell, S. (2004). Cities of Words: Pedagogical Letters on a Register of the Moral Life. Cambridge, Mass: Belknap Press of Harvard University Press.

Cohen, J. (1986). Review of Spheres of Justice, by Michael Walzer. Journal of Philosophy, LXXXIII (8), 457-468.

Dubet, F. (2006). Injustices. L’Expérience des Inégalités au Travail (with Valérie Caillet, Régis Cortéséro, David Mélo, Françoise Rault). Paris : Seuil.

Dworkin, R. \& Walzer, M. (1983). 'Spheres of Justice': An Exchange. The New York Review of Books, 30 (12), 43-46.

Dworkin, R. M. (1993). Life's Dominion: An Argument about Abortion, Euthanasia, and Individual Freedom. New York: Knopf.

Foucault, M. (1986, 1984). The Care of the Self: The History of Sexuality, Vol. III. Translated by Robert Hurley. New York: Parthenon.

Gilligan, C. (1982). In a Different Voice: Psychological Theory and Women's Development. Cambridge,

Mass: Harvard University Press.

Habermas, J. (1984). The Theory of Communicative Action. Boston: Beacon Press.

Habermas, J. (1990). Moral Consciousness and Communicative Action. Cambridge, Mass: MIT Press.

Habermas, J. (1998). On the Pragmatics of Communication. Cambridge, Mass: MIT Press.

Habermas, J. (2000) Crossing Globalization's Valley of Tears. New Perspectives Quarterly, 17(4), 51-56.

Habermas, J. (2005). Une Époque de Transitions. Écrits Politiques 1998-2003. Paris :Fayard.

Habermas, J. (2006). Sur l'Europe. Translated from German by Christian Bouchindhomme et Alexandre

Dupeyrix. Paris, Bayard

Hartmann, M. (2007). The Sociology of Elites. London; New York: Routledge.

Hartmann, M. \& Honneth, A. (2006). Paradoxes of Capitalism. Constellations, 13, 41-58.

Honneth, A. \& Joas, H. (1988). Social Action and Human Nature. Cambridge: [Cambridgeshire]: New York: Cambridge University Press.

Honneth, A. (1995). The Struggle for Recognition: the Moral Grammar of Social Conflicts. Cambridge, Mass: Polity Press.

Honneth, A. (2003). Redistribution as Recognition: A Response to Nancy Fraser. In N. Fraser \& A. Honneth (eds.), Redistribution or Recognition? A Political-Philosophical Exchange (pp.110-197). London: New York: Verso. 
Honneth, A. (2004). Recognition and Justice: Outline of a Plural Theory of Justice. Acta Sociologica, 47(4), 351-64.

Honneth, A. (2006) La Société du Mépris: vers une Nouvelle Théorie Critique. Paris, Éditions La Découverte.

Honneth, A. (2007). Disrespect: The Normative Foundations of Critical Theory. Cambridge: Polity Press.

Honneth, A. \& Anderson, J. (2005). Autonomy, Vulnerability, Recognition, and Justice. In J. Christman \& J. Anderson (eds.), Autonomy and the Challenges to Liberalism: New Essays (pp. 127-149). Cambridge: Cambridge University Press

Illouz, E. (1997). Consuming the Romantic Utopia: Love and the Cultural Contradictions of Capitalism. Berkeley: University of California Press.

Keller, S. (1963). Beyond the Ruling Class: Strategic Elites in Modern Society. New York: Random House.

Kupchan, C. (Ed.). (1995). Nationalism and Nationalities in the New Europe. Ithaca, NY: Cornell University Press.

Locke, J. (1991, 1689). A Letter Concerning Toleration. In J. Horton \& S. Mendus (eds.), A Letter Concerning Toleration, in Focus (pp. 12-56). London: Routledge.

Lovejoy, A. O. (1957). The Great Chain of Being; a Study of the History of an Idea. Cambridge, Mass: Harvard University Press.

Luxton, M. (1980). More Than a Labour of Love: Three Generations of Women's Work in the Home. Toronto: Women Press.

Marshall, T. H. (1950). Citizenship and Social Class: and Other Essays. Cambridge, England: University Press.

McNairn, J. (2000). The Capacity to Judge: Public Opinion and Deliberative Democracy in Upper Canada, 1791-1854. Toronto: University of Toronto Press.

Miquelon, D. (1987). New France, 1701-1744: "A Supplement to Europe". Toronto: McClelland \& Stewart.

Nehamas, A. (1999). Virtues of Authenticity: Essays on Plato and Socrates. Princeton, N.J: Princeton University Press.

Nehamas, A. (1998). The Art of Living: Socratic Reflections from Plato to Foucault. Sather Classical Lectures (Vol. 61). Berkeley: University of California Press.

Parkin, F. (1971). Class Inequality and Political Order: Social Stratification in Capitalist and Communist Societies. London: MacGibbon \& Kee.

Parr, J. (1982). Childhood and Family in Canadian History. Toronto: McClelland \& Stewart.

Parsons, T. (1971). The System of Modern Societies. Englewood Cliffs, N.J: Prentice-Hall.

Rorty, R. (1991). Intellectuals in Politics: Too Far In? Too Far Out? Dissent (Fall): 483-490.

Rorty, R. (1998). Achieving our Country: Leftist Thought in Twentieth-Century America. Cambridge, Mass: Harvard University Press.

Rossler, B. (2007). Work, Recognition and Emancipation. In B. Van den Brink \& D. Owen (eds.), Recognition and Power (pp. 135-164). Cambridge, New York: Cambridge University Press.

Struthers, J. (1983). No Fault of Their Own: Unemployment and the Canadian Welfare State, 1914-1941. Toronto: University of Toronto Press.

Struthers, J. (2002). Unequal Citizenship: The Residualist Legacy in the Canadian Welfare State. In J. English, K. McLaughlin \& P. Whitney Lackenbauer (eds.), Mackenzie King: Citizenship and Community: Essays Marking the 125th Anniversary of the Birth of William Lyon Mackenzie King (pp. 169-185). Toronto: Robin Brass Studio.

Swift, A. (1995). The Sociology of Complex Equality. In D. Miller \& M. Walzer (eds.), Pluralism, Justice, and Equality (pp. 253-280). Oxford, UK: Oxford University Press.

Swift, A. (2004). Would Perfect Mobility be Perfect? European Sociological Review, 20(1), 1-11.

Studies in Social Justice Volume 2, Issue 1, 2008

ISSN: 1911-4788 
Swift, A. (2006). Political Philosophy: A Beginners' Guide for Students and Politicians. Cambridge: Polity Press.

Taylor, C. (1985). Philosophy and the Human Sciences, Philosophical Papers 2. New York: Cambridge Press.

Taylor, C. (1991). The Ethics of Authenticity. Cambridge, MA: Harvard University Press.

Taylor, C. (1993). Reconciling the Solitudes: Essays on Canadian Federalism and Nationalism. Montréal: McGill-Queen's University Press.

Trilling, L. (1972). Sincerity and Authenticity. Cambridge, Mass: Harvard University Press.

Walzer, M. (1983). Spheres of Justice : A Defense of Pluralism and Equality. New York: Basic Books.

Waltzer, M. (1993). Interpretation and Social Criticism. Cambridge, Mass.: Harvard University Press.

Waltzer, M. (2002). The Company of Critics: Social Criticism in the Twentieth Century. New York: Basic Books. 